Earth Syst. Sci. Data Discuss., https://doi.org/10.5194/essd-2018-92

Manuscript under review for journal Earth Syst. Sci. Data

Discussion started: 23 October 2018

(c) Author(s) 2018. CC BY 4.0 License.

(c) (i)

\title{
A new global dataset of phase synchronization of temperature and precipitation: its climatology and contribution to global vegetation productivity
}

\author{
Zhigang Sun ${ }^{1,2}$, Zhu Ouyang ${ }^{1,2}$, Xubo Zhang ${ }^{1}$, Wei Ren ${ }^{3}$
}

$5 \quad{ }^{1}$ Key Laboratory of Ecosystem Network Observation and Modeling, Institute of Geographic Sciences and Natural Resources Research, Chinese Academy of Sciences, Beijing 100101, China

${ }^{2}$ College of Resources and Environment, University of Chinese Academy of Sciences, Beijing 100190, China

${ }^{3}$ College of Agriculture, Food and Environment, University of Kentucky, KY 40546-0091, USA

Correspondence to: Zhigang Sun (sun.zhigang@igsnrr.ac.cn)

10 Abstract. Besides cumulative temperature and precipitation, the phase synchronization of temperature and precipitation also helps to regulate vegetation distribution and productivity across global lands. However, the phase synchronization has been rarely considered in previous studies related to climate and biogeography due to a lack of a robust and quantitative approach. In this study, we proposed a synchronization index of temperature and precipitation (SI-TaP) and then investigated its global spatial distribution, interannual fluctuation, and long-term trend derived from a global 60-year dataset of meteorological

15 forcings. Further investigation was conducted to understand the relationship between SI-TaP and the annually summed Normalized Difference Vegetation Index (NDVI), which could be a proxy of terrestrial vegetation productivity. Results show differences in both spatial patterns and temporal variations between SI-TaP and air temperature and precipitation, but SI-TaP may help to explain the distribution and productivity of terrestrial vegetation. About $60 \%$ of regions where annually summed NDVI is greater than half of its maximum value overlap regions where SI-TaP is greater than half of its maximum

20 value. By using SI-TaP to explain vegetation productivity along with temperature and precipitation, the maximum increase in the coefficient of determination is 0.66 across global lands. Results from this study suggest that the proposed SI-TaP index is helpful to better understand climate change and its relation to the biota.

Dataset available at http://www.dx.doi.org/10.11922/sciencedb.642 or http://www.sciencedb.cn/dataSet/handle/642.

\section{Introduction}

25 Temperature and precipitation are the dominant factors affecting vegetation productivity. Temperature can affect leaf energy balance, metabolic rate, and plant growth rate (Reich and Oleksyn, 2004;Harrison et al., 2010). Precipitation has a strong relationship with plant traits, such as water use efficiency, nutrient cycling, and biomass accumulation (Blackman et al., 2010; Choat et al., 2007). Over recent decades, temperature and precipitation effects on plant growth (ecosystem photosynthesis, respiration, and net primary production (NPP), etc.) and the cycles of water and carbon have been well investigated (Moles et al., 2014;Weltzin et al., 2003;Wu et al., 2011;Moldenhauer and Ludeke, 2002;Schloss et al., 
Earth Syst. Sci. Data Discuss., https://doi.org/10.5194/essd-2018-92

Manuscript under review for journal Earth Syst. Sci. Data

Discussion started: 23 October 2018

(c) Author(s) 2018. CC BY 4.0 License.

(c) (i)

1999;Potter and Brooks, 1998;Heimann and Reichstein, 2008;Foley et al., 1996;Barnes et al., 2016;Jung et al., 2017). The coupling effects of temperature and precipitation on vegetation productivity include amplitudes, accumulative values, and phases. Therefore, the phase synchronization of temperature and precipitation is also a key regulator on vegetation growth; however, it has been seldom investigated in prior studies. Quantifying the degree of this synchronization could improve our understanding of vegetation traits with respect to climate change.

As a typical climate of the phase synchronization of temperature and precipitation, the monsoon is a climate system with seasonal changes in atmospheric circulation and precipitation, which affects the most densely populated regions on the Earth (Zahn, 2003;Trenberth et al., 2000). Its track, duration, and intensity are closely related to the distribution, seasonality, and amount of precipitation; together with temperature, those factors regulate the geographic pattern of plants and animals in

10 monsoon regions (Wahl and Morrill, 2010). Rather than precipitation alone, therefore, the synchronization of temperature and precipitation could be a promising proxy to quantitatively evaluate the effect of monsoon on biogeography.

Generally, there are two quantitative methods for characterizing the synchronization of temperature and precipitation. Crosscorrelation is a typical method to test the synchronization (von Storch and Zwiers, 1999). Alternatively, a phase synchronization method is useful for investigating two or more cyclic systems (or subsystems) which tend to oscillate with a

15 repeating sequence of relative phase angles (Rybski et al., 2003;Tatli, 2007). The cross-correlation method essentially compares the amplitude of meteorological records while the phase synchronization method fundamentally compares the phase of harmonic meteorological records based on harmonic analyses and entropy theory (Rybski et al., 2003). Instead of the complicated calculations and assumptions, a robust but practical synchronization index may provide new insight for investigating the phase synchronization of temperature and precipitation and its impacts on climate assessments.

20 In this study, we proposed a robust and practical index to generate the global yearly-map stack of phase synchronization of temperature and precipitation. Then, the trend of phase synchronization was analyzed. Finally, the contribution of the phase synchronization of temperature and precipitation to vegetation productivity was quantified using a satellite-based vegetation index and the relationship of synchronization index to monsoon was preliminarily discussed.

\section{Method and data}

\section{$25 \quad 2.1$ Defining a synchronization index of air temperature and precipitation}

Summer commonly has high temperature and plenty precipitation for most climates except the Mediterranean climate characterized by dry summer and wet winter (Peel et al., 2007). In this study, we defined a practical index (SI-TaP) to measure the phase synchronization of air temperature (Ta) and precipitation (P) across a whole year for global climates except the Mediterranean climate. For most climates where temperature and precipitation synchronize, the time series of 30 both $\mathrm{Ta}(i)$ and $\mathrm{P}(i)$ could be graphed in unimodal curves, where $i$ ranges from 1 to 365 (or 366 for a leap year) for a given year (from January 1 to December 31 for the Northern Hemisphere, from July 1 to June 30 of the next year for the Southern 
Earth Syst. Sci. Data Discuss., https://doi.org/10.5194/essd-2018-92

Manuscript under review for journal Earth Syst. Sci. Data

Discussion started: 23 October 2018

(c) Author(s) 2018. CC BY 4.0 License.

(c) (i)

Hemisphere). Subsequently, the cumulative time series of $\sum_{t=1}^{t=i} \operatorname{Ta}(t)$ and $\sum_{t=1}^{t=i} \mathrm{P}(t)$ across one year can be simulated using a logistic curve, respectively,

$$
y=\frac{K}{1+a \mathrm{e}^{-b t}},
$$

where $t$ ranges from 1 to $i, y$ represents $\sum_{t=1}^{t=i} \mathrm{Ta}(t)$ or $\sum_{t=1}^{t=i} \mathrm{P}(t), K$ is the upper limit, $a$ is the coefficient of intercept, and $b$ is the curve steepness (Figure 1). The inflection point of $\left(t_{0}, K / 2\right)$ can be obtained using the derivative of the logistic curve, and two critical points of $\left(t_{1},(3-\sqrt{3}) K / 6\right)$ and $\left(t_{2},(3+\sqrt{3}) K / 6\right)$ can be obtained using the second derivative of the logistic curve, where $t_{0}, t_{1}$, and $t_{2}$ can be calculated using the following equations,

$$
\begin{aligned}
& t_{1}=\frac{\ln a+\ln (2-\sqrt{3})}{b}, \\
& t_{0}=\frac{\ln a}{b}, \text { and } \\
& t_{2}=\frac{\ln a+\ln (2+\sqrt{3})}{b} .
\end{aligned}
$$

The lower critical point represents the time after which air temperature or precipitation will increase sharply. The upper critical point represents the time after which air temperature or precipitation will decrease sharply.

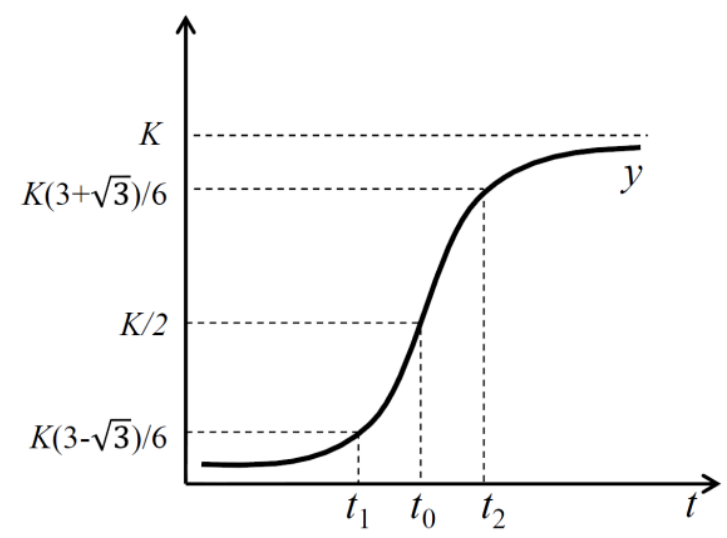

Figure 1. The inflection point and two critical points derived from the logistic curve.

15 Using equations $2 \mathrm{a}$ and $2 \mathrm{c}$, where $a$ and $b$ are calculated by regression analysis of daily temperature time series, two critical time points $\left(t_{1}^{T}, t_{2}^{T}\right)$ can be obtained for the logistic curve of temperature. By the same calculation using daily precipitation time series, two critical time points $\left(t_{1}^{P}, t_{2}^{P}\right)$ can also be obtained for the logistic curve of precipitation. Then, the unitless SI$\mathrm{TaP}$ for a given year can be obtained using the equations listed in Figure 2. Its value ranges from 0 to 1 . The SI-TaP is 1 if the seasonal phase of precipitation exactly matches that of air temperature and is 0 if there is no overlap between seasonal phases of precipitation and air temperature.

The quality of the SI-TaP could be flagged using

$$
\text { Flag }_{\mathrm{SI}-\mathrm{TaP}}=\min \left(R_{T}^{2}, R_{P}^{2}\right),
$$


Earth Syst. Sci. Data Discuss., https://doi.org/10.5194/essd-2018-92

Manuscript under review for journal Earth Syst. Sci. Data

Discussion started: 23 October 2018

(c) Author(s) 2018. CC BY 4.0 License.

(c) (i)

where $R_{T}^{2}$ and $R_{P}^{2}$ are coefficients of determination derived from regression analyses on daily temperature and precipitation time series, respectively.
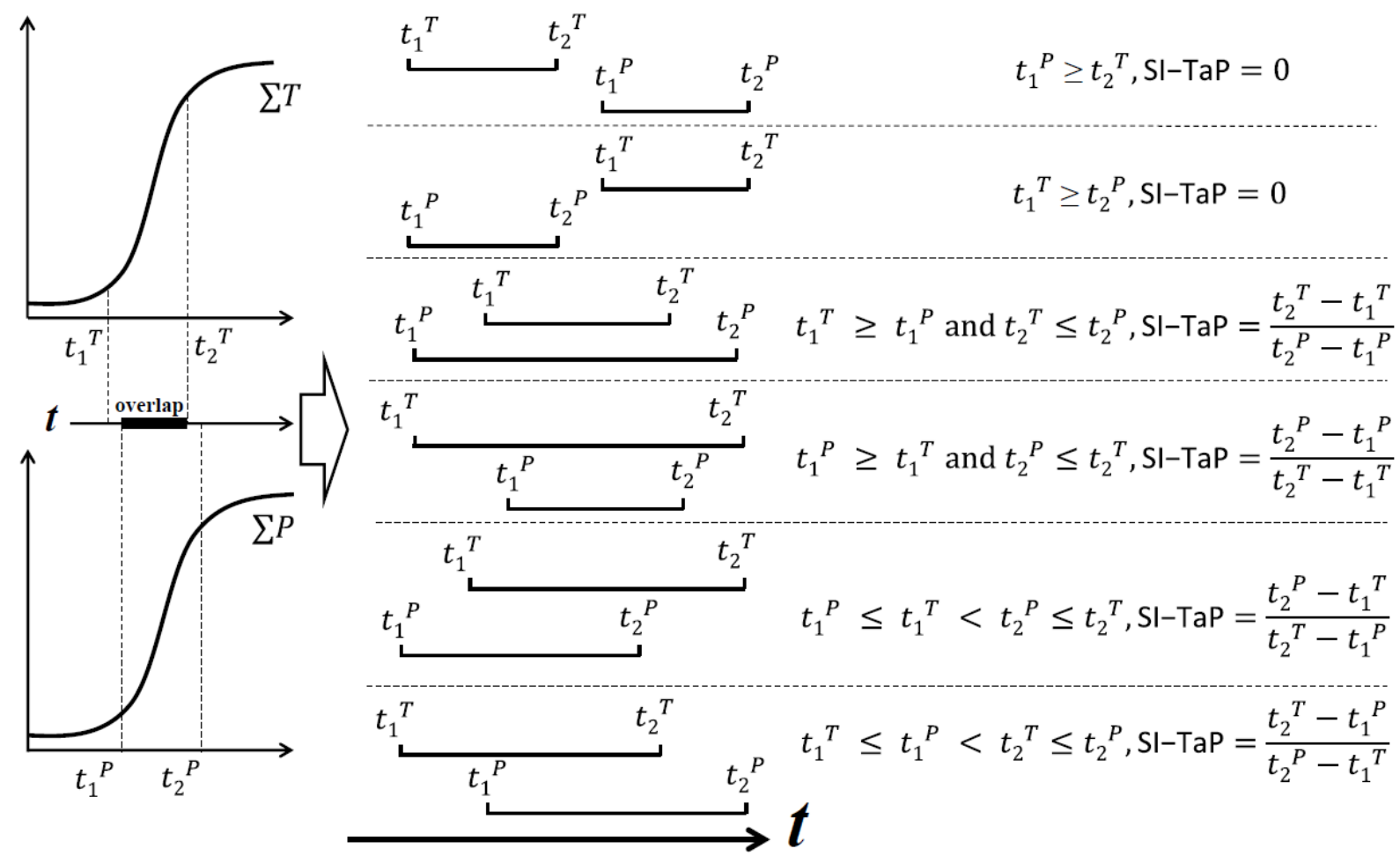

Figure 2. Schematic diagram and equations for calculating the synchronization index of air temperature and precipitation (SI-TaP).

\section{$5 \quad 2.2$ Climate data and vegetation index}

\subsubsection{Global gridded meteorological data}

Global $0.5^{\circ}$ daily air temperature and precipitation data were obtained from the Terrestrial Hydrology Research Group, Princeton University (http://hydrology.princeton.edu/data.pgf.php), where a suite of global observation-based datasets along with the National Centers for Environmental Prediction (NCEP) / the National Center for Atmospheric Research (NCAR) reanalysis were combined and corrected to develop a global 60-year (1948-2008) dataset of meteorological forcings based on the proposed method (Sheffield et al., 2006). In this study, air temperature and precipitation data were used to calculate global SI-TaP. The annual accumulated temperature above $0^{\circ} \mathrm{C}$ and annual precipitation were used to investigate the response of vegetation productivity to temperature, precipitation, and SI-TaP across space and time. 
Earth Syst. Sci. Data Discuss., https://doi.org/10.5194/essd-2018-92

Manuscript under review for journal Earth Syst. Sci. Data

Discussion started: 23 October 2018

(c) Author(s) 2018. CC BY 4.0 License.

(c) (i)

\subsubsection{Remotely sensed vegetation index}

Global GIMMS (Global Inventory Modeling and Mapping Studies) Satellite Drift Corrected NDVI (Normalized Difference Vegetation Index) dataset was accessed via the GLCF (Global Land Cover Facility) (Tucker et al., 2005). This dataset provides 25-year (1981-2006) satellite records of bimonthly changes in the terrestrial vegetation index, with a spatial resolution of $8 \mathrm{~km}$. This size of GIMMS NDVI grid was averagely aggregated to match the $0.5^{\circ}$ global gridded meteorological data. In this study, bimonthly GIMMS NDVI data were annually summed to provide a proxy for terrestrial vegetation productivity (Potter and Brooks, 1998;Schloss et al., 1999;Peng et al., 2012;Peng et al., 2013;Wu et al., 2015). This proxy was used to investigate the response of vegetation productivity to climate and SI-TaP.

With the purpose of matching the available period of GIMMS dataset, the SI-TaP dataset during the 1982-2006 was used for

10 analysis in this study.

\subsection{Statistical Analysis}

\subsubsection{Trend analysis}

The Mann-Kendall test (Kendall, 1975;Gilbert, 1987) was used to test the trend of changes in temperature, precipitation, and SI-TaP in this study. This method has been widely applied in the time series analysis on climatic and hydrological variables

15 (Gocic and Trajkovic, 2013).

\subsubsection{Step-wise linear regression}

Step-wise linear regression was used to understand the contribution of SI-TaP to terrestrial vegetation productivity. Firstly, annually summed NDVI were fitted using the annual accumulated temperature above $0^{\circ} \mathrm{C}$ and annual precipitation. The coefficient of determination $\left(R_{1}^{2}\right)$ could then be obtained. Secondly, annually summed NDVI were fitted using the annual accumulated temperature above 0 , annual precipitation, and SI-TaP. The other coefficient of determination $\left(R_{2}^{2}\right)$ was then also obtained. The difference in the two coefficients of determination $\left(R_{2}^{2}-R_{1}^{2}\right)$ quantifies the contribution of SI-TaP to terrestrial vegetation productivity.

\section{Climatology of SI-TaP and its contribution to global vegetation productivity}

\subsection{Global spatial pattern of SI-TaP and its interannual fluctuation}

25 Yearly gridded SI-TaP during 1982-2006 was calculated for the global climate zones except the Mediterranean climate zones. The gridded mean and standard deviation of SI-TaP were also calculated. The derived map of mean SI-TaP values from 1982 through 2006 shows a spatial pattern of the synchronization of air temperature and precipitation across global lands (Figure 3a). Larger values of SI-TaP are mainly located on both sides of the equator, in southeast of North America, Europe, 
Earth Syst. Sci. Data Discuss., https://doi.org/10.5194/essd-2018-92

Manuscript under review for journal Earth Syst. Sci. Data

Discussion started: 23 October 2018

(c) Author(s) 2018. CC BY 4.0 License.

(c) (i)

Arabian Peninsula, and Eastern Asia in the Northern Hemisphere, and around the $30^{\circ} \mathrm{S}$ latitude line in the Southern

Hemisphere. The global spatial pattern of SI-TaP is quite different from those of air temperature and precipitation. Annual accumulated temperature above $0{ }^{\circ} \mathrm{C}$ has higher values mainly between the $30^{\circ} \mathrm{N}$ and $30^{\circ} \mathrm{S}$ latitude lines (Figure S1). Annual total precipitation has larger values mainly between the $15^{\circ} \mathrm{N}$ and $15^{\circ} \mathrm{S}$ latitude lines and in regions near the oceans (Figure

5 S2).

The standard deviation of SI-TaP could indicate the degree of interannual fluctuation. Figure $3 \mathrm{~b}$ shows that large interannual fluctuation of SI-TaP occurs near the $30^{\circ} \mathrm{N}$ latitude line and around Greenland. The global spatial pattern of the interannual fluctuation of SI-TaP is also different from those of air temperature and precipitation. Annual accumulated temperature exhibits large interannual fluctuation mainly in the middle and western regions of the United States and the Middle East

10 (Figure S3). Annual precipitation has large interannual fluctuation mainly in the equatorial regions and regions near the oceans (Figure S4).

(a)

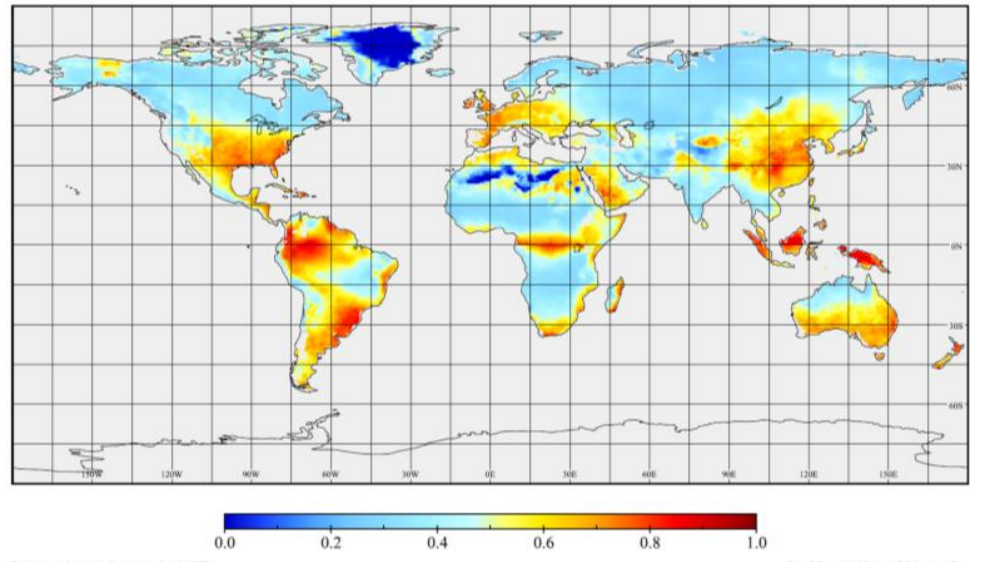

(b)

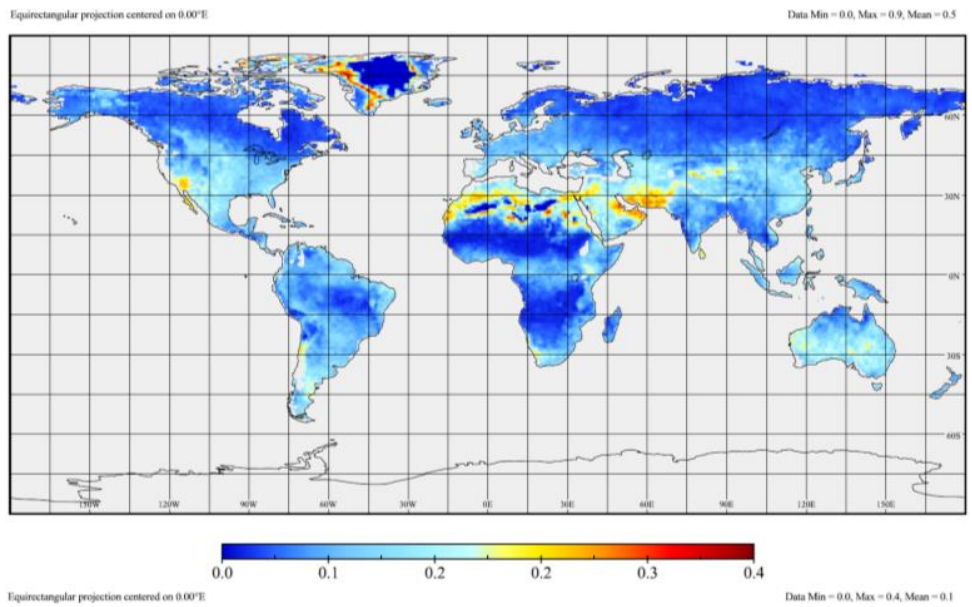

Figure 3. Mean (a) and standard deviation (b) of SI-TaP from 1982 through 2006. 
Earth Syst. Sci. Data Discuss., https://doi.org/10.5194/essd-2018-92

Manuscript under review for journal Earth Syst. Sci. Data

Discussion started: 23 October 2018

(c) Author(s) 2018. CC BY 4.0 License.

(c) (i)

\subsection{Long-term trend of SI-TaP over global lands}

The SI-TaP over global lands presents a significant increasing trend in scattered regions of the United States, northeast Africa, the Middle East, and Australia. The maximum value of an increasing trend reaches 0.009 per year (Figures $4 \mathrm{a}$ and 4b). Decreasing trends are found mainly in South America, the Middle East, Southeastern China, and Australia. The maximum value of a decreasing trend reaches -0.005 per year. However, this decreasing trend is not statistically significant. The average trend of SI-TaP is 0 for global lands, suggesting that there is no significant trend in SI-TaP over the global land surface, despite strong regional responses.

(a)

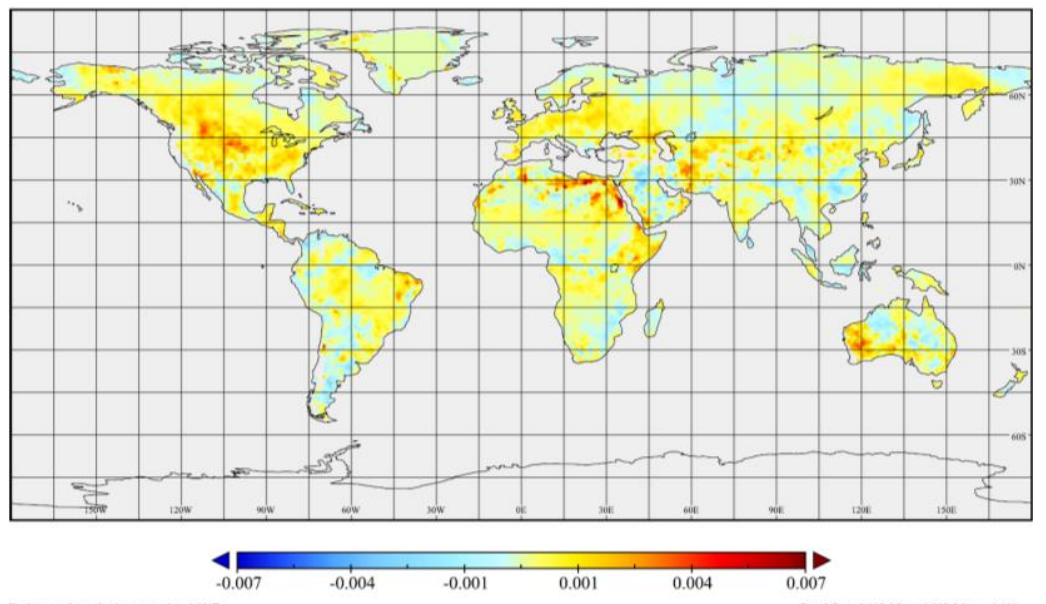

(b)
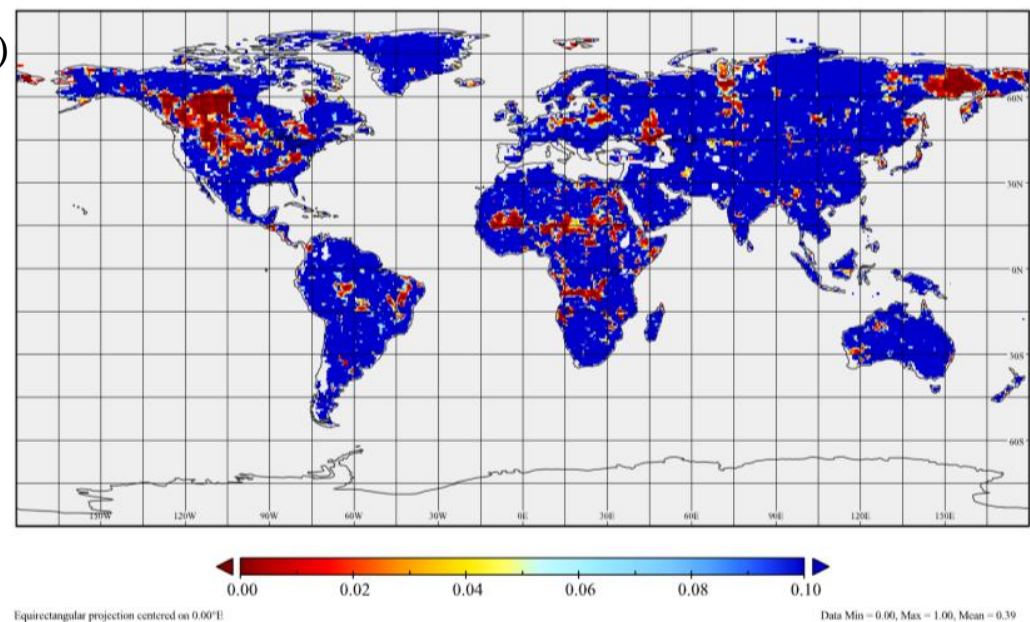

Figure 4. Yearly trend of SI-TaP based on the Mann-Kendall test (a) and $p$-values from the Mann-Kendall test on SI-TaP (b).

The trend of SI-TaP is also different from annual accumulated temperature $\left(>0^{\circ} \mathrm{C}\right)$ and annual precipitation. Annual accumulated temperature shows a significant increasing trend over global lands except for few regions where non-significant 
Earth Syst. Sci. Data Discuss., https://doi.org/10.5194/essd-2018-92

Manuscript under review for journal Earth Syst. Sci. Data

Discussion started: 23 October 2018

(c) Author(s) 2018. CC BY 4.0 License.

(c) (i)

decreasing trends exist (Figures S5a and S5b). The maximum increasing trend is $18{ }^{\circ} \mathrm{C} /$ year and the average increasing trend is $4{ }^{\circ} \mathrm{C} /$ year for global lands. Annual precipitation has a significant increasing trend mainly in western Australia and in scattered regions of North America, South America, and Europe, with a maximum value of $17 \mathrm{~mm} /$ year. It has a significant decreasing trend mainly in equatorial regions in southern Greenland, Africa, India, northern China, and eastern Australia,

5 with a minimum value of $-19 \mathrm{~mm} /$ year (Figures S6a and S6b). However, the average of annual precipitation trend is close to 0 for global lands. This indicates that there is also no significant trend in annual precipitation at the scale of global land.

(a)

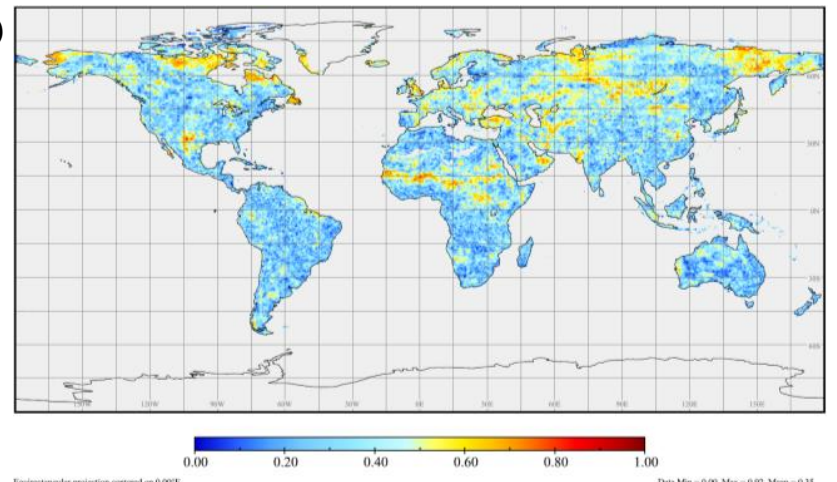

(b)
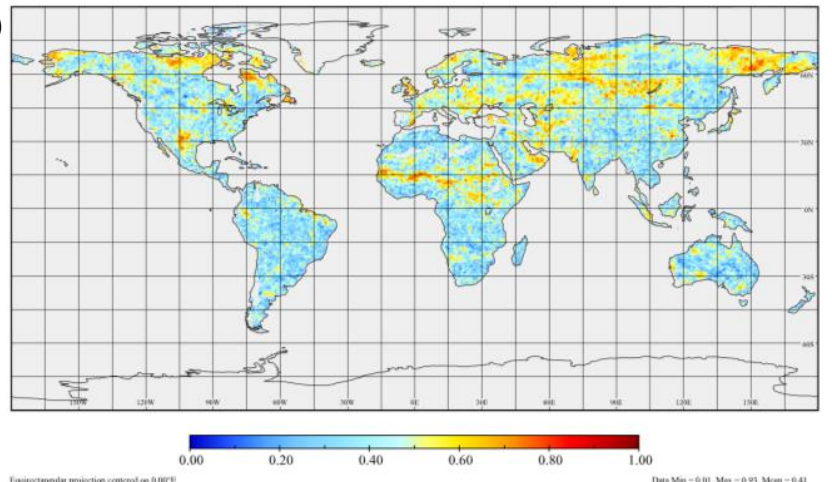

(c)

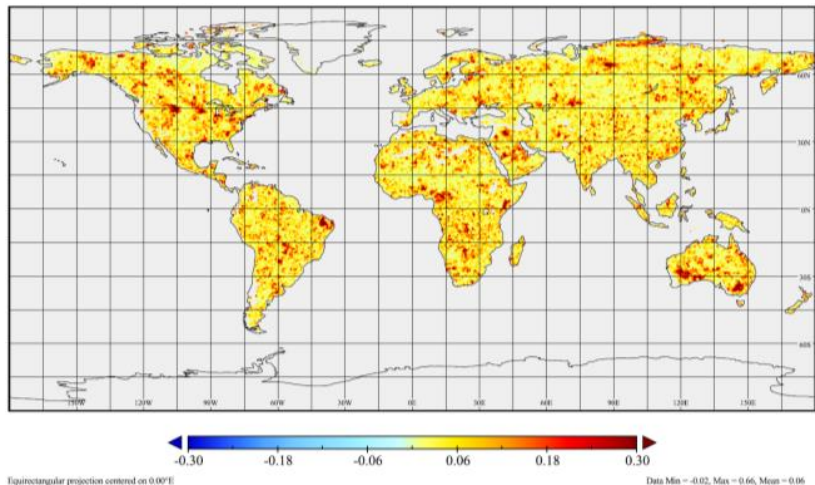

Figure 5. Coefficient of determination $\left(R^{2}\right)$ for linear regression of annually summed NDVI against annual $>0{ }^{\circ} \mathrm{C}$ accumulated temperature and annual precipitation (a), $R^{2}$ for linear regression of annually summed NDVI against annual $>0{ }^{\circ} \mathrm{C}$ accumulated temperature, annual precipitation, and SI-TaP (b), and change in $R^{2}$ after involving SI-TaP (c). 
Earth Syst. Sci. Data Discuss., https://doi.org/10.5194/essd-2018-92

Manuscript under review for journal Earth Syst. Sci. Data

Discussion started: 23 October 2018

(c) Author(s) 2018. CC BY 4.0 License.

\subsection{Contribution of phase synchronization to changes in terrestrial vegetation productivity}

Terrestrial vegetation productivity is mainly affected by accumulated temperature and precipitation. Figure 5a shows a map of coefficient of determination $\left(R_{1}^{2}\right)$ for the linear regression of annually summed NDVI against accumulated temperature and annual precipitation. The maximum value of $R_{1}^{2}$ is 0.92 and the average is 0.35 for global lands. The maximum value of

$5 R_{2}^{2}$ is 0.93 and the average is 0.41 for global lands when SI-TaP is added to fit annually summed NDVI along with accumulated temperature and annual precipitation (Figure $5 \mathrm{~b})$. The difference map $\left(R_{2}^{2}-R_{1}^{2}\right)$ of $R_{2}^{2}$ and $R_{1}^{2}$ shows the added contribution of phase synchronization to terrestrial vegetation productivity across global lands (Figure 5c). The maximum of difference reaches 0.66 and the average is 0.06 for global lands. The regions sensitive to SI-TaP are dotted sporadically across global lands, especially in North America, South America, central and southern Africa, Arabian Peninsula, Russia, and southern Australia.

\section{Further applications of the proposed synchronization index}

\subsection{Relationship of synchronization index to monsoon regions}

As shown in Figure S7, the regional monsoons across the globe include the North American monsoon (NAM), South American monsoon (SAM), North African monsoon (NAF), South African monsoon (SAF), Indian monsoon (IND), East

15 Asian monsoon (EAS), Western North Pacific monsoon (WNP), and the Australian monsoon (AUS) (Chang et al., 2011; Trenberth et al., 2000). An investigation of the overlap of global lands with > 0.5 SI-TaP and monsoon regions shows that $20.44 \%$ of regions with $>0.5 \mathrm{SI}-\mathrm{TaP}$ are located in monsoon regions (Figure 6). The close relationship between SI-TaP and monsoons suggests that the proposed method and results could be quantitatively supportive in studies relating to monsoons and climate change.

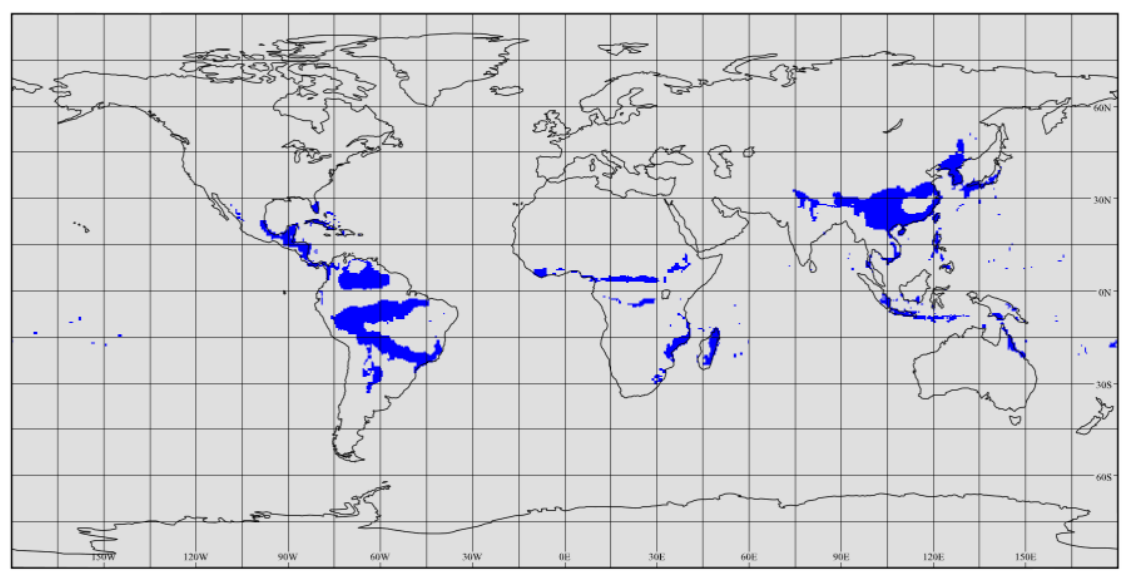

Figure 6. Overlap of global land >0.5 SI-TaP and monsoon regions. (Replotted after Chang et al. (2011), monsoon regions are defined where the local summer-minus-winter precipitation rate exceeds $2.5 \mathrm{~mm} /$ day and the local summer precipitation exceeds $55 \%$ of the annual total). 
Earth Syst. Sci. Data Discuss., https://doi.org/10.5194/essd-2018-92

Manuscript under review for journal Earth Syst. Sci. Data

Discussion started: 23 October 2018

(c) Author(s) 2018. CC BY 4.0 License.

\subsection{Relationship of the synchronization index to vegetation}

Temperature determines the potential vegetation productivity, whereas precipitation along with topography and soil determines the actual vegetation productivity (Seddon et al., 2016). In other words, the amplitude and phase matching of both temperature and precipitation mainly regulate the distribution and productivity of vegetation across global lands (see

5 Figure S8 for global annually summed NDVI map). Many prior studies mainly related the amplitude of temperature and precipitation to plant growth (Potter and Brooks, 1998;Schloss et al., 1999;Moldenhauer and Ludeke, 2002;Moles et al., 2014). Statistical results across global lands in this study illustrate that the phase synchronization of temperature and precipitation can contribute to plant growth (Figure 5). This could be also supported by the overlap of the SI-TaP map of global land and the annually summed NDVI map (Figure 7a). The $55.42 \%$ of regions with $>10$ annually summed NDVI are located in regions with $>0.5$ SI-TaP, whereas only $42.38 \%$ of regions with $>10$ annually summed NDVI are located in monsoon regions (Figure 7b). This high agreement of SI-TaP and vegetation productivity suggests that the proposed synchronization index of temperature and precipitation may contribute to understanding vegetation dynamics with respect to climate change in amplitude and phase.

(a)

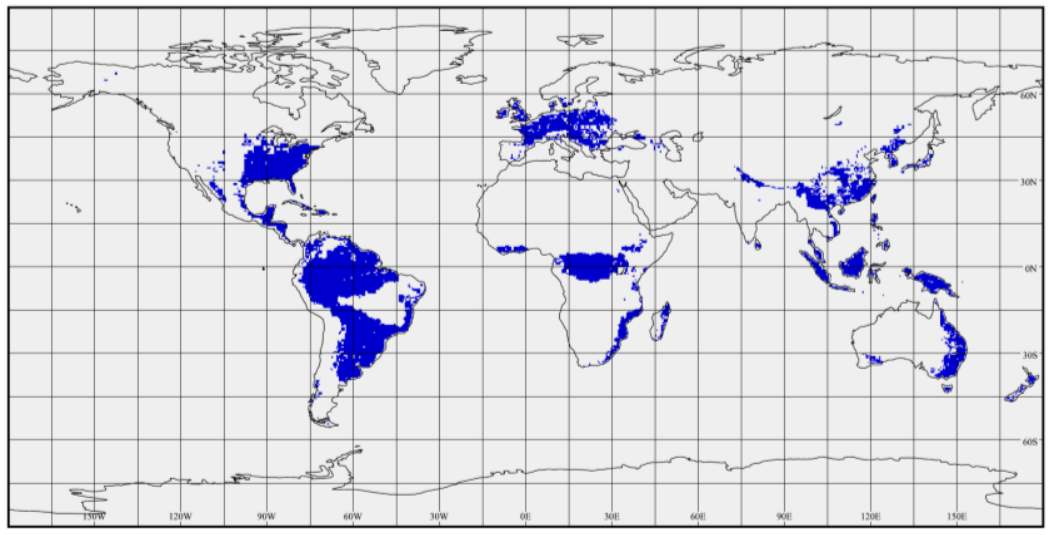

(b)

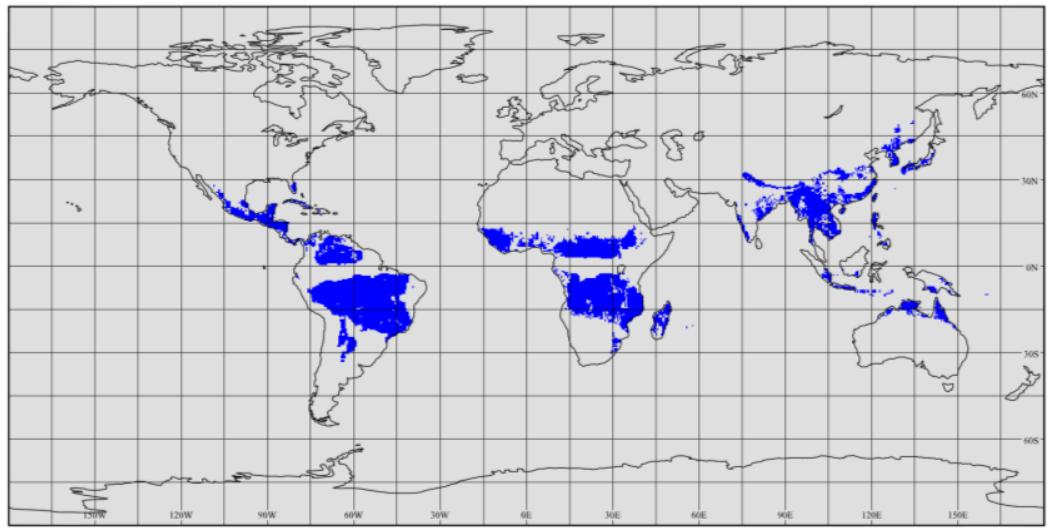

15 Figure 7. Overlap of global lands with $>10$ annually summed NDVI and $>0.5$ SI-TaP (a) and overlap of global lands with $>10$ annually summed NDVI and monsoon regions (b). 
Earth Syst. Sci. Data Discuss., https://doi.org/10.5194/essd-2018-92

Manuscript under review for journal Earth Syst. Sci. Data

Discussion started: 23 October 2018

(c) Author(s) 2018. CC BY 4.0 License.

(c) (i)

\subsection{Potential extensions of the proposed synchronization index}

As compared to air temperature and precipitation, the asymmetric spatial patterns of SI-TaP (unitless) and its interannual fluctuation may provide new insights into climate change and its impacts on vegetation productivity and distribution. The inflection point $\left(t_{0}, K / 2\right)$, which represents the peak of air temperature or precipitation across a whole year, was obtained

5 from Equations 1 and 2 in this study. Therefore, this inflection point can be used to quantify the peak synchronization of air temperature and precipitation. The beginning critical point and the inflection points can be used to further quantify the synchronization of the half phase before the peak. Meanwhile, the ending critical point and the inflection points can also be used to further quantify the synchronization of the half phase after the peak. This provides us with flexible strategies with an actual unite (days) to evaluate phase synchronization during a whole year or a part of a year.

\section{$10 \quad 4.4$ Potential applications of the proposed synchronization index}

The phase synchronization index along with its extended indices discussed above is closely related to recent studies on the impacts of water balance on vegetation phenology and productivity. For example, Jung et al. (2017) presented a climate water index (CWI) to investigate the water balance and how it regulates carbon cycle processes. The indices presented herein could be complementary to climatic indices such as CWI. The proposed indices are also relevant to studies on changing

15 phenology and its impact on the carbon balance. For example, Piao et al. (2008) found that increased carbon uptake was compensated by increased respiratory losses in the fall and Graven et al. (2013) found changes in the phase of $\mathrm{CO}_{2}$ at high latitudes. In further studies, therefore, the SI-TaP and its extended indices could be integrated into broader studies such as phenology and water / carbon / nitrogen balances.

\subsection{Limitations of the proposed synchronization index}

20 Rather than the traditional harmonic analysis methods based on long-term time series data with cosinoidal or sinusoidal seasonality, the proposed synchronization index of temperature and precipitation can be calculated using single-year data and specific numerical equations. This provides a practical, numerical method to quantify the phase synchronization of two variables with seasonal variations. It indicates that the proposed method works not only for climate variables but also for hydrological variables and other variables with seasonal variation. However, the proposed method has its limitations. The calculation of synchronization index is derived from the unimodal seasonal distribution of daily air temperature and precipitation from spring to winter. Therefore, the proposed index may not work for the Mediterranean climates (dry summer and wet winter) due to the bimodal seasonal distribution of daily precipitation across a year. Alternatively, the peak or halfphase synchronization methods mentioned above may be useful for a phase-shift analysis for the Mediterranean climate. The other limitation is that the reliability of the proposed index depends on two sets of regression coefficients of $a$ and $b$ for daily

30 temperature and precipitation time series. In practice, the minimum of two coefficients of determination derived from regression analyses on daily temperature and precipitation time series could be used to flag the quality of the proposed index. 
Earth Syst. Sci. Data Discuss., https://doi.org/10.5194/essd-2018-92

Manuscript under review for journal Earth Syst. Sci. Data

Discussion started: 23 October 2018

(c) Author(s) 2018. CC BY 4.0 License.

(c) (i)

As shown in Figure 8, the proposed index is robust across the global lands except the Greenland Island, North Africa, and the Middle East.

(a)
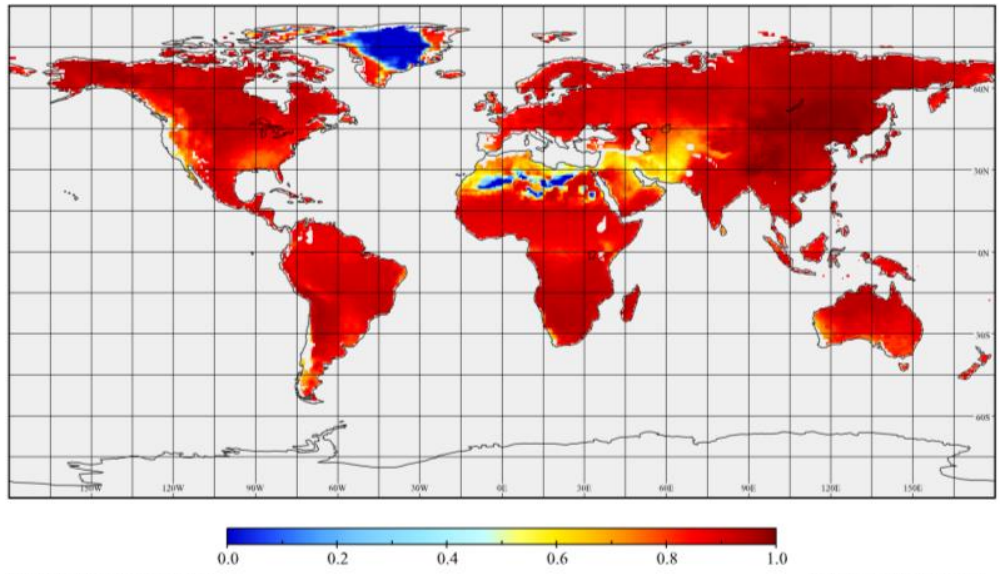

(b)
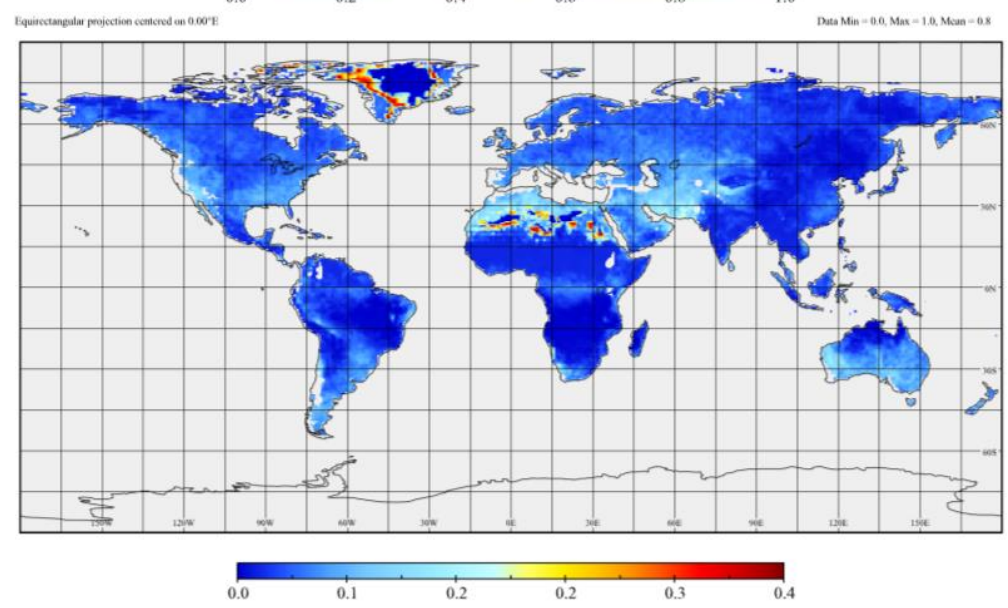

Figure 8. Mean (a) and standard deviation (b) of long-term quality flag raster maps from 1982 through 2006.

\section{Data availability}

The dataset is available from the Science Data Bank, an open generalist data repository (Sun et al., 2018). This dataset includes two files, which is freely accessed at http://www.dx.doi.org/10.11922/sciencedb.642 or http://www.sciencedb.cn/dataSet/handle/642. One file contains the global yearly gridded land SI-TaP from 1948 to 2008. The other file contains the yearly gridded SI-TaP for the whole global from 1948 to 2008. Both files have the spatial

10 resolution of $0.5^{\circ}$. The dataset is stored in the format of netCDF, which could be opened by a wide range of application software that makes use of netCDF files, such as Panoply and ArcGIS versions after 9.2. This dataset could also be read by some programming languages including $\mathrm{C}, \mathrm{C}++$, Fortran, R, Python, IDL, and others through the netCDF API. 
Earth Syst. Sci. Data Discuss., https://doi.org/10.5194/essd-2018-92

Manuscript under review for journal Earth Syst. Sci. Data

Discussion started: 23 October 2018

(c) Author(s) 2018. CC BY 4.0 License.

(c) (i)

\section{Conclusions}

In this study, a robust and practical index (SI-TaP) was proposed to quantitatively investigate the phase synchronization of temperature and precipitation. Our results illustrate that the global distribution, interannual fluctuation, and long-term trend of SI-TaP were different from those of air temperature and precipitation. By adding SI-TaP to explain vegetation

5 productivity along with temperature and precipitation, the maximum increase in the coefficient of determination is 0.66 and the average increase is 0.06 across global lands. The relationships between SI-TaP and monsoon regions and other vegetation traits were further investigated. Our study suggests that the SI-TaP is helpful to explain interannual change in terrestrial vegetation productivity and could aid our understanding of climate change and its relation to the biota.

\section{Acknowledgments}

10 This research was supported by the Strategic Priority Research Program of the Chinese Academy of Sciences (XDA19040303), the National Key Research and Development Program of China (2017YFC0503805), National Natural Science Foundation of China (31570472), the 100 Talents Program of the Chinese Academy of Sciences, and the Science and Technology Service Network Initiative of the Chinese Academy of Sciences (KFJ-EW-STS-054). Authors are particularly grateful to Prof. Qiuhong Tang and anonymous reviewers for their constructive comments, to Dr. Linlin Guo for

15 her work on literature survey, and to Ms. Huixia Ren for her work on programming.

\section{References}

Barnes, M. L., Moran, M. S., Scott, R. L., Kolb, T. E., Ponce-Campos, G. E., Moore, D. J. P., Ross, M. A., Mitra, B., and Dore, S.: Vegetation productivity responds to sub-annual climate conditions across semiarid biomes, Ecosphere, 7, e01339, doi: 10.1002/ecs2.1339, 2016.

20 Blackman, C. J., Brodribb, T. J., and Jordan, G. J.: Leaf hydraulic vulnerability is related to conduit dimensions and drought resistance across a diverse range of woody angiosperms, New Phytologist, 188, 1113-1123, doi:10.1111/j.14698137.2010.03439.x, 2010.

Chang, C. P., Ding, Y., Lau, N. C., Johnson, R. H., Wang, B., and Yasunari, T.: The Global Monsoon System: Research and Forecast, 2nd Edition, Asia-Pacific Weather and Climate, Vol. 5, World Scientific, New Jersey, 2011.

25 Choat, B., Sack, L., and Holbrook, N. M.: Diversity of hydraulic traits in nine Cordia species growing in tropical forests with contrasting precipitation, New Phytologist, 175, 686-698, doi:10.1111/j.1469-8137.2007.02137.x, 2007.

Foley, J. A., Prentice, I. C., Ramankutty, N., Levis, S., Pollard, D., Sitch, S., and Haxeltine, A.: An integrated biosphere model of land surface processes, terrestrial carbon balance, and vegetation dynamics, Global Biogeochemical Cycles, 10, 603-628, doi:10.1029/96gb02692, 1996.

30 Gilbert, R. O.: Statistical methods for environmental pollution monitoring, Van Nostrand Reinhold, New York, 1987. 
Earth Syst. Sci. Data Discuss., https://doi.org/10.5194/essd-2018-92

Manuscript under review for journal Earth Syst. Sci. Data

Discussion started: 23 October 2018

(c) Author(s) 2018. CC BY 4.0 License.

\section{(c) (1)}

Gocic, M., and Trajkovic, S.: Analysis of changes in meteorological variables using Mann-Kendall and Sen's slope estimator statistical tests in Serbia, Global Planet Change, 100, 172-182, doi:10.1016/j.gloplacha.2012.10.014, 2013.

Graven, H. D., Keeling, R. F., Piper, S. C., Patra, P. K., Stephens, B. B., Wofsy, S. C., Welp, L. R., Sweeney, C., Tans, P. P., Kelley, J. J., Daube, B. C., Kort, E. A., Santoni, G. W., and Bent, J. D.: Enhanced Seasonal Exchange of CO2 by Northern 5 Ecosystems Since 1960, Science, 341, 1085-1089, doi:10.1126/science.1239207, 2013.

Harrison, S. P., Prentice, I. C., Barboni, D., Kohfeld, K. E., Ni, J., and Sutra, J.-P.: Ecophysiological and bioclimatic foundations for a global plant functional classification, Journal of Vegetation Science, 21, 300-317, doi:10.1111/j.16541103.2009.01144.x, 2010.

Heimann, M. and Reichstein, M.: Terrestrial ecosystem carbon dynamics and climate feedbacks, Nature, 451, 289-292, 10 doi:10.1038/nature06591, 2008.

Jung, M., Reichstein, M., Schwalm, C. R., Huntingford, C., Sitch, S., Ahlstrom, A., Arneth, A., Camps-Valls, G., Ciais, P., Friedlingstein, P., Gans, F., Ichii, K., Ain, A. K. J., Kato, E., Papale, D., Poulter, B., Raduly, B., Rodenbeck, C., Tramontana, G., Viovy, N., Wang, Y. P., Weber, U., Zaehle, S., and Zeng, N.: Compensatory water effects link yearly global land CO2 sink changes to temperature, Nature, 541, doi:10.1038/nature20780, 2017.

15 Kendall, M. G.: Rank correlation methods, 4th ed., Charles Griffin, London, 1975.

Moldenhauer, O., and Ludeke, M. K. B.: Climate sensitivity of global terrestrial net primary production (NPP) calculated using the reduced-form model NNN, Climate Research, 21, 43-57, doi:10.3354/cr021043, 2002.

Moles, A. T., Perkins, S. E., Laffan, S. W., Flores-Moreno, H., Awasthy, M., Tindall, M. L., Sack, L., Pitman, A., Kattge, J., Aarssen, L. W., Anand, M., Bahn, M., Blonder, B., Cavender-Bares, J., Cornelissen, J. H. C., Cornwell, W. K., Diaz, S.,

20 Dickie, J. B., Freschet, G. T., Griffiths, J. G., Gutierrez, A. G., Hemmings, F. A., Hickler, T., Hitchcock, T. D., Keighery, M., Kleyer, M., Kurokawa, H., Leishman, M. R., Liu, K. W., Niinemets, U., Onipchenko, V., Onoda, Y., Penuelas, J., Pillar, V. D., Reich, P. B., Shiodera, S., Siefert, A., Sosinski, E. E., Soudzilovskaia, N. A., Swaine, E. K., Swenson, N. G., van Bodegom, P. M., Warman, L., Weiher, E., Wright, I. J., Zhang, H. X., Zobel, M., and Bonser, S. P.: Which is a better predictor of plant traits: temperature or precipitation?, Journal of Vegetation Science, 25, 1167-1180, doi:10.1111/jvs.12190, 2014.

Peel, M. C., Finlayson, B. L., and McMahon, T. A.: Updated world map of the Koppen-Geiger climate classification, Hydrol Earth Syst Sc, 11, 1633-1644, 2007.

Peng, D., Zhang, B., Liu, L., Fang, H., Chen, D., Hu, Y., and Liu, L.: Characteristics and drivers of global NDVI-based FPAR from 1982 to 2006, Global Biogeochemical Cycles, 26, doi:10.1029/2011gb004060, 2012.

30 Peng, S. S., Piao, S. L., Ciais, P., Myneni, R. B., Chen, A. P., Chevallier, F., Dolman, A. J., Janssens, I. A., Penuelas, J., Zhang, G. X., Vicca, S., Wan, S. Q., Wang, S. P., and Zeng, H.: Asymmetric effects of daytime and night-time warming on Northern Hemisphere vegetation, Nature, 501, 88-92, doi:10.1038/nature12434, 2013. 
Earth Syst. Sci. Data Discuss., https://doi.org/10.5194/essd-2018-92

Manuscript under review for journal Earth Syst. Sci. Data

Discussion started: 23 October 2018

(c) Author(s) 2018. CC BY 4.0 License.

(c) (i)

Piao, S. L., Ciais, P., Friedlingstein, P., Peylin, P., Reichstein, M., Luyssaert, S., Margolis, H., Fang, J. Y., Barr, A., Chen, A. P., Grelle, A., Hollinger, D. Y., Laurila, T., Lindroth, A., Richardson, A. D., and Vesala, T.: Net carbon dioxide losses of northern ecosystems in response to autumn warming, Nature, 451, 49-U43, doi:10.1038/nature06444, 2008.

Potter, C. S. and Brooks, V.: Global analysis of empirical relations between annual climate and seasonality of NDVI,

5 International Journal of Remote Sensing, 19, 2921-2948, doi:10.1080/014311698214352, 1998.

Reich, P. B., and Oleksyn, J.: Global patterns of plant leaf N and P in relation to temperature and latitude, Proceedings of the National Academy of Sciences of the United States of America, 101, 11001-11006, doi:10.1073/pnas.0403588101, 2004.

Rybski, D., Havlin, S., and Bunde, A.: Phase synchronization in temperature and precipitation records, Physica A: Statistical Mechanics and its Applications, 320, 601-610, doi:10.1016/s0378-4371(02)01509-1, 2003.

10 Schloss, A. L., Kicklighter, D. W., Kaduk, J., Wittenberg, U., and Intercomparison, P. P. N. M.: Comparing global models of terrestrial net primary productivity (NPP): comparison of NPP to climate and the Normalized Difference Vegetation Index (NDVI), Global Change Biology, 5, 25-34, doi:10.1046/j.1365-2486.1999.00004.x, 1999.

Seddon, A. W. R., Macias-Fauria, M., Long, P. R., Benz, D., and Willis, K. J.: Sensitivity of global terrestrial ecosystems to climate variability, Nature, 531, 229-232, doi:10.1038/nature16986, 2016.

15 Sheffield, J., Goteti, G., and Wood, E. F.: Development of a 50-year high-resolution global dataset of meteorological forcings for land surface modeling, J Climate, 19, 3088-3111, doi:10.1175/Jcli3790.1, 2006.

Sun, Z., Ouyang, Z., Zhang, X., and Ren, W.: A new global dataset of phase synchronization of temperature and precipitation, Science Data Bank, http://www.dx.doi.org/10.11922/sciencedb.642, 2018.

Tatli, H.: Synchronization between the North Sea-Caspian pattern (NCP) and surface air temperatures in NCEP,

20 International Journal of Climatology, 27, 1171-1187, doi:10.1002/joc.1465, 2007.

Trenberth, K. E., Stepaniak, D. P., and Caron, J. M.: The global monsoon as seen through the divergent atmospheric circulation, J Climate, 13, 3969-3993, doi: 10.1175/1520-0442(2000)013<3969:Tgmast>2.0.Co;2, 2000.

Tucker, C. J., Pinzon, J. E., Brown, M. E., Slayback, D. A., Pak, E. W., Mahoney, R., Vermote, E. F., and El Saleous, N.: An extended AVHRR 8-km NDVI dataset compatible with MODIS and SPOT vegetation NDVI data, International Journal of

25 Remote Sensing, 26, 4485-4498, doi:10.1080/01431160500168686, 2005.

von Storch, H., and Zwiers, F. W.: Statistical Analysis in Climate Research, Springer, Cambridge University Press, Cambridge, 1999.

Wahl, E. R., and Morrill, C.: CLIMATE CHANGE Toward Understanding and Predicting Monsoon Patterns, Science, 328, 437-438, doi:10.1126/science.1188926, 2010.

30 Weltzin, J. F., Loik, M. E., Schwinning, S., Williams, D. G., Fay, P. A., Haddad, B. M., Harte, J., Huxman, T. E., Knapp, A. K., Lin, G. H., Pockman, W. T., Shaw, M. R., Small, E. E., Smith, M. D., Smith, S. D., Tissue, D. T., and Zak, J. C.: Assessing the response of terrestrial ecosystems to potential changes in precipitation, Bioscience, 53, 941-952, doi:10.1641/0006-3568(2003)053[0941:Atrote]2.0.Co;2, 2003. 
Earth Syst. Sci. Data Discuss., https://doi.org/10.5194/essd-2018-92

Manuscript under review for journal Earth Syst. Sci. Data

Discussion started: 23 October 2018

(c) Author(s) 2018. CC BY 4.0 License.

(c) (1)

Wu, D. H., Zhao, X., Liang, S. L., Zhou, T., Huang, K. C., Tang, B. J., and Zhao, W. Q.: Time-lag effects of global vegetation responses to climate change, Global Change Biology, 21, 3520-3531, doi:10.1111/gcb.12945, 2015.

Wu, Z., Dijkstra, P., Koch, G. W., PeÑUelas, J., and Hungate, B. A.: Responses of terrestrial ecosystems to temperature and precipitation change: a meta-analysis of experimental manipulation, Global Change Biology, 17, 927-942, 5 doi:10.1111/j.1365-2486.2010.02302.x, 2011.

Zahn, R.: Global change - Monsoon linkages, Nature, 421, 324-325, doi:10.1038/421324a, 2003. 